\title{
Persuasão e propaganda: os limites da retórica na sociedade mediatizada
}

Paulo Serra*

Resumo: Inventada no tempo dos gregos, a retórica foi obrigada logo desde os seus inícios a coexistir com uma outra estratégia de persuasão: a propaganda; e a coexistir de uma forma tal que se pode mesmo dizer que a retórica nasceu apesar de e mesmo contra a propaganda. Não sendo uma invenção contemporânea, foi contudo a sociedade contemporânea que erigiu a propaganda como a estratégia central de persuasão a mobilizar, na guerra ou na paz, por governos, empresas, partidos, igrejas e todo o tipo de instituições e organizações. Pretendemos no que se segue, por um lado, distinguir a retórica e a propaganda enquanto estratégias de persuasão; e, por outro lado, analisar as relações que ambas entretêm no contexto mais geral da persuasão. A este respeito, a nossa tese é a de que a propaganda, enquanto modalidade plutocrática da persuasão, tem como um dos seus objectivos essenciais o de condicionar as formas democráticas de persuasão, consubstanciadas na retórica.

Palavras-chave: retórica, propaganda, persuasão, democracia.

\section{Retórica e opinião pública}

A situação de persuasão tal como descrita por Aristóteles, na sua Retórica, é uma situação ideal - de uma idealização que decorre da própria natureza especulativa ou teorética da tarefa que o filósofo se propõe.

Essa idealização verifica-se quer na definição que Aristóteles nos dá de retórica como "a faculdade de descobrir especulativamente o que, em cada caso, pode ser susceptível de persuadir» (1355b, itálicos meus) -, quer na distinção que faz entre as provas artísticas - as que são inventadas pelo orador e, portanto, patentes na pronunciação do 
seu discurso - e as não artísticas - as que, como acontece com «testemunhos, confissões sob tortura, documentos escritos, e outras semelhantes», precedem o discurso do orador e podem ser por este utilizadas para apoiar esse mesmo discurso (1355b-1356a).

Em relação à definição de retórica, a questão é que, praticamente, só podemos saber o que é efectivamente susceptível de persuadir a posteriori, isto é, depois de tomada a decisão pelo auditório; e é sempre muito mais fácil dizer de um orador, depois de proferido o seu discurso, que ele não conseguiu persuadir um determinado auditório porque não utilizou os meios de persuasão mais adequados do que indicar-lhe, previamente, que meios deveria ter utilizado para persuadir aquele.

Relativamente à distinção entre provas artísticas e não artísticas é também praticamente impossível separar umas das outras, já que, como referem Perelman e OlbrechtsTyteca (1976: 430), ainda que a propósito de um tipo de sociedade que não a grega (a nossa), "na maior parte dos casos o orador é conhecido, seja porque fala perante um auditório familiar, seja porque se sabe quem ele é, graças à imprensa e a todas as formas de publicidade. A vida do orador, na medida em que ela é pública, constitui um longo preâmbulo ao seu discurso».

Mas a situação de persuasão é idealizada por Aristóteles ainda num outro sentido: na medida em que pressupõe que um certo orador, utilizando os meios de persuasão mais adequados a um determinado auditório, conseguirá, necessariamente, persuadir esse mesmo auditório de uma determinada tese. ${ }^{1}$

Ora, como é do conhecimento de cada um daqueles que já se envolveram numa situação de persuasão - quer dizer, de cada um de nós -, nem sempre, numa situação de persuasão, o orador que o auditório, ou a maioria deste, considera que é o mais credível e/ou o que utiliza os argumentos mais adequados - pensemos numa assembleia política, num tribunal ou, de forma mais geral, em situações que há que decidir sobre o futuro ou julgar sobre o passado - se revela praticamente como o mais persuasivo. ${ }^{2}$ Em muitas dessas situações, diga o orador o que disser, faça o orador o que fizer, ele nunca chegará a persuadir o auditório - muito simplesmente porque este já se encontra persuadido à partida, e num sentido contrário ao visado pelo orador. Longe de estar disposto a analisar a acção e os meios de persuasão do orador de uma forma imparcial e justa, o auditório revela-se, logo de início, como parcial. Não é inusual, nestas situações, um membro do auditório confessar mesmo, ao orador, que «Em princípio, até estou de acordo consigo, mas...» É precisamente este mas, anterior ao debate, que aqui nos interessa.

Há várias causas para esta parcialidade - prévia, apriorística - do auditório em relação a um orador, à sua tese e aos seus argumentos.

\footnotetext{
${ }^{1}$ Esta situação de persuasão ideal, que nunca existiu, pressupõe uma sociedade ideal, que também nunca existiu.

2 Não se infira daqui o contrário, isto é, que em determinadas circunstâncias um discurso não poderia ser decisivo ainda que nem sempre no sentido pretendido/desejável. Como observa Hermógenes a Sócrates na Apologia de Sócrates de Xenofonte, «Mas, não vês como, muitas vezes, nos tribunais atenienses, por causa de um discurso, condenaram aqueles que não cometeram qualquer injustiça, e como, pelo contrário, muitas vezes também absolveram os culpados, ou porque se compadeceram com o seu discurso ou porque falaram de modo mais agradável?» (Xenofonte in Pinheiro, 2003: 157).
} 
Uma delas é, sem dúvida, aquilo a que podemos chamar os «interesses» - políticos, económicos, sociais ou outros - do auditório. Assim, numa reunião política, dificilmente um marxista conseguirá persuadir um auditório de grandes industriais no sentido da «abolição da propriedade privada dos meios de produção»; ou, num debate parlamentar, dificilmente o deputado da situação persuadirá o deputado da oposição a votar numa proposta do governo, por melhor que esta pareça para a nação; ou ainda, numa eleição para um qualquer cargo, dificilmente o eleitor deixará de votar no candidato que lhe prometeu uma qualquer benesse, para votar naquele que apresenta o melhor programa de acção ou a melhor equipa.

Outra dessas causas, e que aqui nos interessa em particular, tem a ver com a "opinião pública», com aquilo a que, no seu clássico sobre o tema, Lippmann (1998: 3) chama «the pictures in our heads».

Uma das melhores ilustrações da influência da «opinião pública» - dos estereótipos ou pré-juízos colectivos - na decisão de uma situação de persuasão é, seguramente, o julgamento e condenação de Sócrates, tal como descritos por Platão na sua Apologia. Como o próprio Sócrates reconhece, no seu discurso inicial, as acusações mais temíveis que enfrenta não são as «novas» - as presentes ao tribunal por Meleto e corroboradas por Ânito e Lícon,$-{ }^{3}$ mas antes as «antigas»: a «fama» negativa que, ao longo dos anos, se foi construindo em volta dele, com o contributo decisivo de Aristófanes e da sua comédia As Nuvens. ${ }^{4} \mathrm{E}$ isso porque, refere o filósofo, se trata de acusações feitas ao longo de muitos anos, quando os jurados eram ainda crianças ou rapazes e, portanto, mais crédulos, por acusadores geralmente anónimos e que, persuadidos, persuadiam por sua vez outros, e assim sucessivamente (Platão, 18a-e). Ao que acresce - e isto é decisivo para o que aqui intentamos demonstrar - que, na impossibilidade de fazer comparecer todos esses acusadores anónimos perante o tribunal, diz Sócrates, "Só posso defender-me deles combatendo contra sombras e refutá-los sem que ninguém me responda.» (Platão, $18 \mathrm{~d}$ ). Ora, como o decurso do julgamento vai mostrar, combater contra «sombras» revela-se uma tarefa impossível. É certo que, já depois de condenado à morte, Sócrates atribui a impotência da sua argumentação não propriamente à «fama» negativa com que chegou ao tribunal mas à falta do tempo necessário para a rebater argumentativamente. ${ }^{5}$ Resta, no entanto, saber de quanto tempo necessitaria Sócrates para tal. Toda a sua vida futura? E, mesmo assim, teria Sócrates o sucesso pretendido? ${ }^{6}$

\footnotetext{
3 E que podem ser vistos, na linha do que dissemos, como representantes dos «interesses», supostamente atacados por Sócrates, respectivamente dos poetas, dos comerciantes e dos oradores.

${ }^{4} \mathrm{~A}$ fama de «homem sabedor, que investiga os fenómenos celestes e pesquisa tudo o que se passa debaixo da terra e faz dos argumentos fracos fortes argumentos» (cita Sócrates os seus acusadores) e que, por conseguinte, não acreditará nos deuses (Platão, 18 b-c).

5 «Estou convencido de que nunca fiz voluntariamente qualquer mal a homem algum, mas também sei que não consigo convencer-vos disso. Falámos durante tão pouco tempo. Creio que, se houvesse entre nós uma lei, como há noutras cidades, que determinasse que os casos de morte não pudessem ser julgados num único dia, mas em vários, acabaria por vos persuadir. Mas não é fácil dissipar em tão pouco tempo tão grandes calúnias.» (Platão, 37 b).

${ }^{6}$ É preciso lembrar, apesar de tudo, que Sócrates não foi condenado de forma unânime: «Dos vários testemunhos apresentados, calcula-se, para os juízes do tribunal que o condenou, o número de 502: Platão refere (Ap. 36a) que o número de votos a favor da condenação ultrapassava em 60 os votos contra, que, diz Diógenes Laércio (2.41), teriam sido 281; de onde o cálculo: 281+(281-60)=502.» (Pinheiro, 2003: 144).
} 
Pois, não o esqueçamos, é precisamente com toda a sua vida - passada - que Sócrates argumenta, sem sucesso, contra os que argumentam em seu desfavor. ${ }^{7}$

Assim, e ao contrário do que aparenta pretender Platão, o seu mestre Sócrates não é propriamente vítima da retórica - dessa arte de lutar com a apresentação de si e o discurso que seria intrinsecamente alheia à verdade -, mas antes da opinião comum, dessa doxa que está antes e é exterior à retórica. Sócrates não morreu por um excesso de retórica, mas antes por um seu defeito: um pouco mais de retórica e Sócrates teria, certamente, sobrevivido.

\section{A afirmação da propaganda}

Este problema do tempo necessário à persuasão - que é, no fundo, o tempo necessário à democracia - é mencionado também, muitos séculos depois e num contexto bastante diferente do da sociedade grega coetânea de Sócrates, por Sinclair Lewis no seu romance Babbitt. Nessa obra de 1922, e cuja acção é situada pelo autor em 1920 (Lewis, 2003: 8), ao caracterizar a personagem Howard Littlefield - bacharel em Artes pelo Blodgett College e doutorado em Economia por Yale, director do pessoal e conselheiro de publicidade da Zenith Street Traction Company -, Lewis refere que

Era capaz, se lhe dessem dez horas, de comparecer perante o conselho municipal ou o parlamento estadual e provar, absolutamente, com números em colunas e com precedentes da Polónia e da Nova Zelândia, que a companhia de carros-eléctricos amava o Público e ansiava pelo bem-estar dos seus empregados; que todas as suas acções eram propriedade de Viúvas e Órfãos; e que fosse lá o que fosse que se propunha fazer beneficiaria os proprietários dos terrenos aumentando o valor lucrativo e ajudaria os pobres reduzindo as rendas. (Lewis, 2003: 28)

Este excerto de Babbitt, para além de mostrar como os processos de persuasão teorizados por Aristóteles, assentes na comunicação oral e presencial, continuam a ter uma importância decisiva no novo tipo de democracia - a que se tem vindo a chamar «liberal», "capitalista», "de massas», etc. -, mostra também como os processos de persuasão surgem, agora, dominados por um outro tipo de motivações, de índole económica e empresarial.

No entanto, e tal como no caso de Sócrates, também neste exemplo não é seguro que, mesmo sendo-lhe dadas as tais dez horas, Littlefield fosse efectivamente capaz de provar "absolutamente» tudo aquilo que se diz. Há mesmo razões fundadas para crermos que, seja em função do seus interesses, nomeadamente económicos e políticos, seja em função das opiniões "públicas» vigentes nas suas comunidades, os membros de

\footnotetext{
7 Este aspecto ainda é mais visível na Apologia de Sócrates de Xenofonte, segundo a qual Sócrates teria mesmo recusado defender-se através de «argumentos», justificando-se perante Hermógenes da seguinte forma: «Porque nunca cometi qualquer acção injusta, e é esse comportamento que eu considero, precisamente, a melhor maneira de preparar uma defesa.» (Xenofonte in Pinheiro, 2003: 156-7).
} 
ambos os auditórios referidos se dividiriam em dois ou mais partidos, podendo acontecer que a maioria deles até não fosse favorável aos argumentos de Littlefield.

Numa outra passagem do seu romance, Lewis descreve um outro tipo de estratégia persuasiva, idealizada pela personagem George Babbitt para fazer aumentar as adesões e as colectas da Escola Dominical Presbiteriana de Chatam Road:

O jovem Kenneth Escort, repórter do Advocate-Times, foi nomeado agente de publicidade da Escola Dominical Presbiteriana de Chatam Road. Dava-lhe seis horas por semana. Pelo menos era pago para dar seis horas por semana. Tinha amigos na Press e na Gazette e não era (oficialmente) conhecido como agente de publicidade. Forneceu aos amigos uma série de sugestões para artigos sobre a boa vizinhança e a Bíblia, sobre os jantares escolares, alegres mas educativos, e sobre o valor da oração para alcançar êxito financeiro. (Lewis, 2003: 194)

O que aqui se descreve sob o nome de «publicidade» é, na realidade, uma parte essencial daquilo que Edward L. Bernays, mais ou menos na altura em que se situa o romance de Lewis, começava a denominar «relações públicas»e «propaganda» - ainda que o termo "publicidade» fosse, por vezes, também por si utilizado. Refira-se, aliás, que o próprio Bernays, ao abrir em 1919 um escritório em Nova Iorque, começa por chamar à sua actividade "publicity direction", para adoptar, em 1920, a designação "public relations counsel»(Bernays, 1961: xxxiii-xxxiv); mas isso não o impede de, em 1928, dar a um dos seus livros mais conhecidos e citados sobre relações públicas o título de Propaganda.

O excerto citado torna perfeitamente claro o objectivo essencial deste tipo de persuasão, que virá a assumir uma importância decisiva nas sociedades contemporâneas: ${ }^{8}$ a construção de uma "opinião pública" favorável a uma determinada entidade (ideia, pessoa, grupo, empresa, instituição) e que, anterior e exterior à tomada de decisões relativa a essa entidade - um voto, uma compra, uma adesão, uma dádiva -, permita que ela se faça, no menor tempo possível, no sentido favorável a essa mesma entidade.

Compreende-se, assim, que num dos passos de Propaganda Bernays (1928: 25) defina a propaganda moderna como «um esforço consistente e persistente para criar ou configurar acontecimentos para influenciar as relações do público com uma empresa, ideia ou grupo", uma "prática para criar circunstâncias e imagens nas mentes de milhões de pessoas». ${ }^{9}$ No que se refere à relação entre propaganda e relações públicas, Bernays (1928: 37) define o "conselheiro de relações públicas» como o "propagandista que se especializa em interpretar empresas e ideias para o público, e em interpretar o público para os criadores de novas empresas e ideias». As relações públicas são, portanto, uma espécie desse género que é a propaganda. Já sobre a distinção entre propaganda

\footnotetext{
8 De que não é, no entanto, uma criação. De facto, na revisão histórica que faz no prefácio à edição de 1961 da obra Crystallizing Public Opinion, Bernays faz remontar a propaganda à Suméria, à Babilónia, à Síria e à Pérsia, e a meios como as estátuas e outros monumentos (Bernays, 1961: vi). Este ponto de vista é partilhado por Jowett e O’Donnell (2006: 50), de acordo com os quais «The use of propaganda as a means of controlling information flow, managing public opinion, or manipulating behavior, is as old as recorded history».

${ }^{9}$ A tradução desta e das outras citações feitas no corpo do texto é da minha responsabilidade.
} 
e publicidade, também relevante neste contexto, refere Lasswell (1927: 628) que "A publicidade (advertising) é divulgação (publicity) paga e pode ser ou não utilizada na propaganda»; uma posição mais ou menos subscrita por Newman (2004: xiii), quando afirma que "As empresas tendem a não usar 'media pagos', que é aquilo a que chamam publicidade (adverts). Preferem usar 'media livres' - aquilo a que chamam notícias.»

Quanto à forma como se efectua a propaganda, o excerto de Babbitt citado permite destacar pelo menos três aspectos:

i) Mediático: recorre aos meios de comunicação de difusão, aqui exemplificados pelo jornal, de forma a atingir, ao mesmo tempo, o maior número de pessoas possível - os tais «milhões de pessoas» de que fala Bernays - e, assim, construir a opinião pública favorável que se pretende. Hoje, esse recurso tem o seu aspecto mais visível, mas não exclusivo, na elaboração e envio maciço de press-releases a jornais, rádios e televisões, que decidem da sua publicação ou não, ipsis verbis ou com algum tratamento jornalístico.

ii) Indirecto: realiza-se essencialmente não através de processos que visam, de forma explícita e directa, a persuasão dos seus destinatários, ${ }^{10}$ mas através de um conjunto de acções, alegadamente sem intuitos persuasivos, em que ganham especial destaque os eventos destinados a tornar-se "acontecimentos mediáticos», a transmissão de «informações» destinadas a "esclarecer» o público e a publicação de histórias com interesse humano feita por jornalistas de órgãos noticiosos oficiais e reputados. No limite, este carácter indirecto das campanhas conduz àquilo a que, no seu conhecido livro de 1957, Vance Packard (2007: 31ss) denuncia como «persuasão oculta».

iii) Para-jornalístico: os aspectos anteriores permitem perceber porque é que, ainda hoje, a propaganda é feita por profissionais provenientes do campo do jornalismo ou dotados de formação aprofundada nessa área e, por isso mesmo, capacitados para produzirem o tipo de informação que os jornais e os jornalistas consideram adequado ao seu público e estarão, por conseguinte, dispostos a publicar. ${ }^{11}$ Isto mesmo se é certo que há muito que a actividade de propaganda e relações públicas não é protagonizada pela velha figura do «agente de publicidade» de que fala o texto de Lewis, mas antes por agências - ditas «de publicidade», de «relações públicas» ou, mais recentemente, "de comunicação" -, isto é, organizações altamente especializadas e discretas, que trabalham para governos, empresas e outras instituições, movimentando nalguns casos verbas muito avultadas, e cujo conjunto constitui aquilo a que se tem vindo a designar as «indústrias da persuasão» (Pearson \& Turner, 1965; Fidalgo, 2008a).

\footnotetext{
${ }^{10}$ Como defenderemos adiante, este é um dos aspectos decisivos para se distinguir entre retórica e propaganda.

${ }^{11}$ Refere Dowie (2004: 2), a este propósito, que «about a third of America's currently practicing PR men and women began their careers as journalists, where they learned how to investigate people and institutions, how newsrooms work and how to write a compelling and informative story. In a strange way many of tem still are journalists. Academicians who study media now estimate that about $40 \%$ of all 'news' flows virtually unedited from the public relations offices, prompting a prominent exec to boast that 'the best PR ends up looking the news'».
} 
Aos aspectos anteriores deveremos juntar ainda os seguintes, não patentes no excerto de Babbitt mas decorrentes da teorização e da prática da propaganda que Edward Bernays fazia no período subsequente àquele em que se publicou aquele romance:

iv) Científico: a propaganda moderna baseia-se não só na psicologia de massas, nomeadamente nos trabalhos de Le Bon, Trotter e Freud, entre outros, mas também em ciências como a sociologia, a economia, etc., e nos seus métodos e técnicas de investigação da opinião pública. Foi precisamente tendo em conta os dados destas várias ciências que Bernays estabeleceu, como princípios fundamentais, a orientação das campanhas para os líderes dos grupos, mais do que para os indivíduos em geral, e o apelo às motivações afectivas e inconscientes dos indivíduos e grupos (o pathos), mais do que às suas motivações racionais e conscientes (logos), em cujo poder Bernays parecia acreditar pouco. ${ }^{12}$

v) Sistemático: a propaganda moderna assenta não em acções improvisadas e desgarradas, mas na ideia de campanha - um termo que deriva, claramente, do domínio militar -, entendida como um conjunto de acções planificadas, dirigidas a um certo conjunto de pessoas, ao longo de um certo tempo e visando objectivos muito específicos, definidos em função das pretensões do cliente, seja ele um político, um partido, uma empresa, etc.

vi) Multiforme: no sentido de se dirigir aos indivíduos e aos grupos utilizando todos as formas e meios de comunicação disponíveis e considerados como os mais adequados/eficazes, incluindo a publicidade. Neste conjunto de meios, os mass media ocupam, sem dúvida, um papel de destaque, não só pela sua potência comunicacional como pelo número de destinatários que permitem atingir - pelo que o agendamento e o enquadramento mediático das acções da campanha se revelam como essenciais para o propagandista e o seu cliente.

Tendo em conta o anterior, a estratégia típica seguida por Bernays nas suas campanhas $^{13}$ envolvia geralmente as acções seguintes, não necessariamente por esta ordem:

- Criar um evento notável e, portanto, noticiável pelos meios de comunicação de massa;

- fornecer, aos jornalistas, informação sobre o produto, preferentemente sob a forma de histórias com interesse humano e em forma publicável;

\footnotetext{
12 Veja-se, por exemplo: «Men are rarely aware of the real reasons which motivate their actions. A man may believe that he buys a motor car because, after careful study of the technical features of all makes on the market, he has concluded that this is the best. He is almost certainly fooling himself. He bought it, perhaps, because a friend whose financial acumen he respects bought one last week; or because his neighbors believed he was not able to afford a car of that class; or because its colors are those of his college fraternity.» (Bernays, 1928: 51). E, noutro passo, a propósito da «escola de Freud», acrescenta Bernays (1928: 52): «An engineer may know all about the cylinders and pistons of a locomotive, but unless he knows how steam behaves under pressure he cannot make his engine run. Human desires are the steam which makes the social machine work».

${ }^{13}$ De que uma das mais famosas é a que efectua, a partir de 1928, para a American Tobacco Company, produtora do Lucky Strike, para levar mais mulheres a fumar (Tye, 2002: 23-50).
} 
- dar informação “ verdadeira” - que não possa ser mostrada como falsa - sobre o produto a promover;

- mobilizar apoios credíveis, nomeadamente de especialistas e cientistas de renome, mas não só, em relação a esse mesmo produto;

- criar e financiar organizações de cidadãos que defendam «desinteressadamente» o produto.

Para ilustramos alguns dos processos essenciais da propaganda a que acabámos de nos referir, analisaremos na secção seguinte a mais recente "campanha institucional» da EDP.

\section{A campanha da EDP sobre as barragens}

Em 24 de Abril de 2009, a EDP lança uma «campanha institucional» relacionada com a construção de novas barragens, subordinada ao lema "Quando projectamos uma barragem projectamos um futuro melhor» (EDP, 2009). O objectivo é claro: mostrar aos portugueses todos os alegados benefícios - a lista deles é bastante extensa - que a construção de barragens traz para a fauna (sobrevivência das espécies em extinção, biodiversidade), a flora (desenvolvimento sustentável da floresta) e as populações (postos de trabalho, desenvolvimento económico, energia não poluente, diminuição de incêndios, etc.).

A campanha que a EDP anuncia é, diz ela própria, uma campanha «multi-meios», envolvendo a televisão, o cinema, a imprensa, a rádio, mupis, a internet e edifícios da EDP; tem uma duração prevista de cinco semanas; inclui a criação e a interpretação,

por Paulo Gonzo, de uma canção intitulada «Espelho (De Outra Água)»; é criada pela McCann Ericksson (concepção) e pela Krypton (produção); para a sua preparação são filmadas e fotografadas várias espécies animais, algumas raras e de origem não portuguesa, em locais como a Serra do Gerês, a Serra da Estrela e a barragem de Castelo de Bode; são filmadas ainda grande parte do Zêzere e oito barragens por todo o país; todo este conjunto de filmagens mobiliza um grande conjunto de meios materiais e humanos, neste caso sessenta pessoas durante cinco dias (EDP, 2009: 24 de Abril).

$\mathrm{O}$ anúncio da campanha é noticiado, nesse mesmo dia, pela generalidade dos media noticiosos portugueses, que referem a Lusa como fonte. Os títulos das notícias não se referem, de forma directa, à campanha da EDP, mas antes ao concerto que, para marcar o início da mesma, o cantor Paulo Gonzo irá dar numa divisão subterrânea da barragem do Alto Lindoso, a 340 metros de profundidade (cf. por exemplo Expresso, 2009: 24 de Abril; Jornal de Notícias, 2009: 24 de Abril; Sol, 2009: 24 de Abril).

Um primeiro aspecto digno de nota é o de que, tendo a mesma fonte, não seria de admirar que as notícias dadas pelos diferentes meios de comunicação tivessem mais ou menos o mesmo conteúdo - mas já é de admirar que essa identidade seja quase total (as frases, o estilo, a estrutura, etc.). De facto, verifica-se que as notícias publicadas, tendo como fonte a Lusa, se limitam praticamente a transcrever, sem aspas, dois comunicados da própria EDP - isto é, a dizer da EDP e da sua campanha o que ela própria diz, palavra por palavra. Referimo-nos, mais concretamente, ao comunicado intitulado «EDP lança 
nova campanha institucional dedicada à energia hídrica», com data de 24 de Abril, e, ainda que em menor proporção, ao intitulado «EDP investe 3000 milhões de euros em barragens até 2016", de 23 de Abril (EDP, 2009: 24 de Abril; EDP, 2009: 23 de Abril). O que dizemos pode ser facilmente comprovado no Anexo 1, onde incluímos apenas alguns exemplos, de meios noticiosos tão prestigiados como o Expresso, o Jornal de Notícias ou o Sol, e apenas de algumas partes das respectivas «notícias». Peças de teor muito semelhante, ainda que mais abreviadas, são publicadas na Visão, no Diário Digital, na RTP1 e na SIC; a TVI, para além de anunciar repetidamente o evento, efectua a transmissão em directo do concerto de Paulo Gonzo que marca a abertura da campanha.

Um segundo aspecto digno de nota é o de que nenhuma das «notícias» desses meios noticiosos, até por se terem praticamente limitado a reproduzir, via Lusa, os comunicados da EDP, se refere ao facto de a construção de muitas das barragens - por exemplo a do Tua, ou a do Sabor - estar envolvida em acesa polémica, merecendo a oposição declarada da generalidade das associações ambientalistas e de certas populações. Ora, é essa oposição que, de facto, justifica em última análise a campanha da EDP - que, em termos práticos, visa criar na população portuguesa em geral um clima de opinião favorável à construção das barragens e aos seus impactos positivos e, reciprocamente, esbater ou apagar a consciência dessa população acerca dos eventuais impactos negativos das mesmas, bem como a argumentação subjacente.

Ambos os aspectos - o mero copy paste e a falta de contextualização da notícia, do por$q u \hat{e}$ - acabam por indicar que, de facto, a estratégia da EDP e das agências por si contratadas foi, logo no início da colocação da campanha no terreno, bastante bem sucedida: fez passar a propaganda como "notícia», isto é, como acontecimento de interesse (do) público e desqualificou, de forma sub-reptícia, a credibilidade e os argumentos da oposição.

Praticamente duas semanas depois de iniciada a campanha da EDP - em 10 de Maio de 2009 -, e com o apoio explícito daquela empresa, a TSF começou a emitir um programa «informativo» intitulado «Energia da Água - Terra-a-Terra Especial», que o website daquela Rádio publicita da seguinte forma:

O que mudou ou vai mudar nas localidades à volta das barragens? A TSF faz-se ao caminho e percorre o país à procura de respostas. Uma barragem é produção de energia, mas é também turismo, agricultura, ecologia.

Energia da Água - Terra-a-Terra Especial, um programa com o apoio da EDP.

Aos domingos, entre as 09h00 e as 11h00 (TSF, 2009: 10 de Maio).

Até 26 de Julho de 2009, inclusive, foram emitidos os seguintes programas:

2009-05-10 Barragens como energia renovável e segurança energética

2009-05-15 Barragens: Energia da Água - Terra-a-Terra Especial

2009-05-17 Barragem do Baixo Sabor

2009-05-24 Barragem de Miranda do Douro

2009-05-31 Os impactos ambientais provocados pela construção de uma barragem

2009-06-14 Barragem de Fridão

2009-06-21 O complexo Cávado- Lima 


\begin{abstract}
2009-06-28 A barragem do Alvito
2009-07-05 Barragem do Bagaúste

2009-07-12 Barragem de Foz Tua

2009-07-19 As barragens como grandes obras de engenharia

2009-07-26 Barragem de Ribeiradio
\end{abstract}

Apenas duas observações sobre este conjunto de programas.

Primeira observação: o programa inicial, de 10 de Maio de 2009, intitula-se «Barragens como energia renovável e segurança energética» e é anunciado no site da TSF da seguinte forma:

No lançamento do programa Energia da Água - Terra-a-Terra Especial, falamos da importância das barragens como energias renováveis e como factor decisivo para reduzir a dependência energética do país. Participam neste programa o Eng. Pedro Neves Ferreira, Director de Planeamento Energético da EDP, o Eng. Francisco Saraiva, Director da Divisão de Planeamento de Longo Prazo da REN, o prof. Gomes Martins, vice-reitor da Universidade de Coimbra e professor catedrático da Faculdade de Ciência e Tecnologia da UC e prof. catedrático do departamento de Engenharia Electrónica e de Computadores da Universidade do Porto (TSF, 2009: 10 de Maio).

Mostra-se aqui algo que se repete nos outros programas: por um lado, a utilização de uma terminologia que praticamente reproduz a utilizada pela EDP - e com a qual, seguramente, os ambientalistas e as populações que se opõem às barragens não estarão certamente de acordo; por outro lado, o recurso a responsáveis da EDP, cientistas, académicos, funcionários governamentais (directores de Parques Naturais, por exemplo) e, nos programas sobre as barragens concretas, autarcas das regiões afectadas - e que, em geral, se manifestam interessados e/ou têm mesmo interesses na construção das barragens.

Segunda observação: dos doze programas emitidos entre 10 de Maio e 26 de Julho de 2009, apenas um, o de 31 de Maio, tratou de «Os impactos ambientais provocados pela construção de uma barragem» e contou com a presença de membros de ONG ambientalistas - e, mesmo assim, apenas dois: Paula Chainho, dirigente da Liga para a Protecção da Natureza, e Domingos Patacho, dirigente da Quercus (TSF, 2009: 31 de Maio).

Verifica-se, assim, que quer em termos dos temas escolhidos, quer em termos dos participantes, quer ainda em termos da linguagem utilizada na sua promoção, este conjunto de programas «informativos» faz passar, para a opinião pública, uma posição praticamente coincidente com a da EDP.

E quanto à (o)posição dos ambientalistas? As ONG da área do Ambiente ${ }^{14}$ respondem à campanha da EDP a 30 de Abril, pedindo a sua suspensão, na medida em que, alegam, «associa erradamente as barragens à protecção da biodiversidade, quando na verdade a sua construção significa uma forte ameaça tanto às populações humanas como

\footnotetext{
${ }^{14}$ Concretamente a Plataforma Sabor Livre, o FAPAS (Fundo para a Protecção dos Animais Selvagens), o GEOTA (Grupo de Estudos de Ordenamento do Território e Ambiente), a LPN (Liga para a Protecção da Natureza), a Quercus (Associação Nacional de Conservação da Natureza) e a SPEA (Sociedade Portuguesa para o Estudo das Aves).
} 
às espécies silvestres, não só as referidas na própria campanha - aves rupícolas, peixes, lobos, morcegos e flora - mas todas as constantes da biodiversidade específica de cada habitat» (Plataforma Sabor Livre et al., 2009: 30 de Abril). Apesar das «medidas impostas à EDP para tentar minimizar ou compensar parte dos danos ambientais provocados pela construção de barragens", os impactos negativos continuam, segundo estas ONG, a verificar-se. Assim, aquilo que a EDP chama uma «campanha institucional» não é, para os ambientalistas, senão uma "campanha de desinformação» (a expressão é deles).

Diga-se, em abono da verdade, que a forma como a generalidade dos meios noticiosos veicula a posição dos ambientalistas é mais ou menos análoga à que vimos em relação aos comunicados da EDP - citando a Lusa como fonte e transcrevendo, no todo ou em parte, o comunicado das ONG (cf. por exemplo Diário de Notícias, 2009: 30 de Abril; Público, 2009: 30 de Abril; Visão, 2009: 30 Abril).

Mas isso só prova que a prática do copy paste é uma rotina «jornalística» solidamente estabelecida - e da qual, obviamente, todas as agências e agentes que procuram uma ou outra forma de agendamento mediático tiram o melhor proveito. Não prova, de forma nenhuma, que haja uma igualdade quanto à atenção, ao tempo e ao espaço que os meios noticiosos dão às posições antagónicas da EDP e dos ambientalistas. De facto, do lado da EDP temos, ao longo de várias semanas, todos os dias, não só uma campanha cara, maciça e poderosa dispersa pelos diversos meios, mas também a atenção, financeiramente apoiada, de um conjunto de programas «noticiosos» como os da TSF, que veiculam «objectivamente» as posições e argumentos da empresa. Já do lado dos ambientalistas, as referências à sua posição nos meios noticiosos desde 30 de Abril podem contar-se praticamente pelos dedos de uma mão; existem apenas quando, como a generalidade das ONG já aprendeu, se provoca um acontecimento mediático que dificilmente pode ser ignorado pelos meios noticiosos - como foi o caso quando, em 13 de Junho de 2009, elementos da Quercus decidiram cortar o trânsito na barragem de Belver como forma de protesto não só contra a construção das barragens mas também contra a campanha da EDP (Sol, 2009: 13 de Junho).

\section{Propaganda e democracia}

Para Jowett e O’Donnell (2006: 1), que não estão sozinhos neste ponto, há uma distinção clara entre propaganda e persuasão: "A propaganda é uma forma de comunicação que tenta conseguir uma resposta que vá ao encontro do intento desejado pelo propagandista. A persuasão é interactiva e tenta satisfazer as necessidades quer do persuasor quer do persuadido.»

Ora, esta distinção é problemática a vários níveis.

Em primeiro lugar, por separar propaganda e persuasão - uma separação que não é sustentável, nem do ponto de vista da história dos conceitos, nem do ponto de vista da análise dos mesmos. Quanto ao ponto de vista histórico, ao marcar a diferença entre a «antiguidade» e a "vida moderna», Harold Lasswell, sublinhava já, num texto de 1927 dedicado à propaganda política, que "A maior parte do que antigamente podia ser feito pela violência e intimidação tem de ser feito agora por argumento e persuasão. A 
democracia proclamou a ditadura do palavrear, e a técnica de ditar ao ditador chama-se propaganda.» (Lasswell, 1927: 631). A propaganda é, por conseguinte, uma forma de poder alternativa à violência e à intimidação, porque assente na palavra, nos argumentos e na persuasão. Quanto ao ponto de vista analítico, a persuasão é definida, por Petty e Cacioppo como "uma tentativa activa para mudar a mente de uma pessoa» (Petty $\&$ Cacioppo, 1996: 4), e isso simultaneamente ao triplo nível das suas atitudes, crenças e comportamentos (ibidem: 6-7). Ora, parece fora de dúvidas que, ao procurar criar ou modificar nas pessoas uma posição, favorável ou desfavorável, em relação a uma certa entidade, a propaganda se enquadra de forma perfeita na definição de "persuasão". Mais recentemente, ao referirem-se à relação - e distinção - entre propaganda e relações públicas, Morris e Goldsworthy (2008: 109-110) afirmam que «a propaganda é talvez mais bem vista como descrevendo a orquestra da persuasão. O propagandista explora todas as possibilidades de influenciar o pensamento e a acção humanos» num processo que pode incluir a educação, a arte, a música, o desporto, os discursos, etc.; quanto às relações públicas, elas constituem «uma secção significativa dentro da orquestra», podendo ser vistas como "uma resposta, inicialmente por parte de interesses comerciais e governos, ao poder crescente dos mass media» e à necessidade de lidar com eles. Assim, e ao contrário do que defendem Jowett e O’Donnell, a separação a fazer não será entre propaganda e persuasão mas entre propaganda e retórica, entre uma persuasão pela via da propaganda e uma persuasão pela via da retórica.

Em segundo lugar, a distinção de Jowett e O’Donnell é problemática ao contrapor o objectivo da propaganda de "conseguir uma resposta que vá ao encontro do intento desejado pelo propagandista", do objectivo da persuasão (retórica) de tentar "satisfazer as necessidades quer do persuasor quer do persuadido». Com efeito, não é óbvio que, na retórica - relembre-se o julgamento de Sócrates -, o persuasor não procure satisfazer o seu intento, em prejuízo do intento do persuadido; nem, tão-pouco, que na propaganda não haja atenção às necessidades do "persuadido" - quando, por exemplo, uma empresa faz propaganda de um produto que considera o melhor para os consumidores, ou um governo faz propaganda de uma lei que considera como a mais adequada para os cidadãos.

Em terceiro lugar, a distinção de Jowett e O’Donnell é problemática pela oposição que faz entre uma persuasão (retórica) interactiva e uma propaganda que seria não interactiva. A não ser que se defenda uma teoria da comunicação radicalmente «hipodérmica", em ambos os casos a interactividade, mais ou menos profunda, aparece como uma característica e uma necessidade da comunicação - sob pena de esta não chegar sequer a existir. Assim, e para darmos apenas um exemplo, nada obsta a que se faça a propaganda do racismo e da violência através de um jogo «interactivo» de computador em que o jogadores ganham tanto mais pontos quanto mais pessoas de uma determinada raça ou etnia são capazes de eliminar.

Em quarto e último lugar, e apesar de este aspecto não se encontrar explícito na distinção de Jowett e O’Donnell, também não é especificamente pela mediatização que a propaganda se distingue da retórica. De facto, e como argumentam Fidalgo e Ferreira (2005), tem todo o sentido falar-se, hoje, de uma "retórica mediatizada", claramente visível em meios como a televisão ou a Internet, mas não só; e, por outro lado, nada 
impede que a propaganda se faça de uma forma oral e presencial - pensemos por exemplo num comício político.

Mas, se não é pelo seu objectivo, pelo tipo de interesses dos intervenientes, pela interactividade, pela mediatização, o que é que distingue, no essencial, a persuasão propagandística da persuasão retórica?

A nossa tese, nesta matéria, e que pensamos ser a conclusão lógica deste texto, é a de que a persuasão retórica, tal como a concebe Aristóteles - assente na ideia de que não há verdades absolutas e que, por conseguinte, toda a verdade deve ser estabelecida de forma agonística, mediante o exame e o debate das várias teses em presença -, continua a ser um instrumento essencial da democracia. ${ }^{15} \mathrm{~A}$ propaganda, ao apresentar-se a si mesma, não como persuasão mas como informação, é, de facto, uma espécie de "grau zero da persuasão» - tal como, a propósito de uma escrita cuja ideal de estilo seria a própria ausência de estilo, Barthes falava de um "grau zero da escrita». ${ }^{16}$ Enquanto tal, ela tem a pretensão implícita de substituir a argumentação pelos «factos», a discussão pela «objectividade», e, assim, condicionar todo o debate - retórico, democrático ulterior. Ora, esse condicionamento é sempre obra e objectivo de um certo grupo de interesses que são, em última instância, económicos. ${ }^{17}$ Assim, o condicionamento da retórica pela propaganda não é outra coisa senão o condicionamento da democracia pela plutocracia - que é o que, no fundo, também significa a personagem Babbitt do romance homónimo de Sinclair Lewis. É por isso que hoje, como na Grécia, a propaganda - e não a retórica - tem de ser vista como um perigo para a democracia.

\section{Referências}

Aristóteles (1998). Retórica, Lisboa: Imprensa Nacional-Casa da Moeda.

Bernays, E. L. (1928). Propaganda, New York: Horace Liveright.

Bernays, E. L. (1961). Crystallizing Pubic Opinion. New York: Liveright Publishing Corporation (original 1923).

Diário de Notícias (2009, 30 de Abril). 'Ambientalistas acusam EDP de branquear efeitos de barragens' [http://dn.sapo.pt/Common/print.aspx?content_id=1217775, consultado em 18/05/2009].

Dijk, T. A. van (1998). News as Discourse, Hillsdale NJ: Lawrence Erlabaum Associates.

Dowie, M. (2004). 'Introduction to the US edition: Torches of liberty' in Stauber, J. \& Rampton, S. (2004) Toxic Sludge is Food for You. Lies, damn lies and the public relations industry, London: Robinson, 1-16. Lewis, S. (2003). Babbitt, Lisboa: Bibliotex.

EDP (2009). Nova Campanha de Barragens [http://www.servicos.edp.pt/Download/6/barragens.html, consultado em 18/05/2009].

EDP (2009, 23 de Abril). EDP investe 3000 milhões em energia hidrica [http://www.edp.pt/EDPI/Internet/PT/ Group/Media/EDPNews/estrategiaEDPhidricas.htm, consultado em 18/05/2009].

$\operatorname{EDP}(2009,24$ de Abril). EDP lança nova campanha institucional dedicada à energia hídrica [http://www.edp. pt/EDPI/Internet/PT/Group/Media/EDPNews/2009/CampanhaBarragens.htm, consultado em 18/05/2009].

Expresso (2009, 24 de Abril). 'Gonzo dá concerto a 340 metros de profundidade' [http://aeiou.expresso.pt/ gen.pl?p=print\&op=view\&fokey=ex.stories/510700\&sid=ex, consultado em 18/05/2009].

\footnotetext{
${ }^{15}$ Sobre a relação indissociável entre retórica e democracia cf. Fidalgo, 2008b.

${ }^{16}$ A propósito da «retórica das notícias» Teun van Dijk fala, precisamente, de uma «persuasão assertiva» que «é o nível zero dos processos persuasivos» (Dijk, 1988: 83).

${ }^{17}$ A tese de uma informação mediática submetida aos interesses dominantes, configurando um «modelo da propaganda», é justamente a tese central de Herman \& Chomsky, 1994.
} 
Fidalgo, A. \& Ferreira, I. (2005). 'A retórica mediatizada', Revista de Comunicação e Linguagens, Lisboa: CECL.

Fidalgo, A. (2008a). 'Da retórica às indústrias da persuasão', Comunicação apresentada no Rhetoric and Argumentation in the Beginning of the 21st Century 2008, International Commemorative Colloquium (1958-2008) of Traité de l'Argumentation: La nouvelle rhétorique of C. Perelman and L. OlbrechtsTyteca and The Uses of Argument, of S. Toulmin, 2 a 4 de Outubro de 2008, Faculdade de Letras da Universidade de Coimbra.

Fidalgo, A. (2008b). 'Definição de retórica e cultura grega', Biblioteca Online de Ciências da Comunicação [http://www.bocc.ubi.pt, consultado em 5/08/2009].

Herman, E. S. \& Chomsky, N. (1994). Manufacturing Consent: The political economy of the mass media, London: Vintage.

Jornal de Notícias (2009, 24 de Abril). 'Paulo Gonzo canta a 340 metros de profundidade' [http://jn.sapo.pt/ Common/print.aspx?content_id=1211155, consultado em 18/05/2009].

Jowett, G. S. \& O’Donnell, V. (2006). Propaganda and Persuasion, Thousand Oaks: Sage Publications.

Lasswell, H. D. (1927). 'The Theory of Political Propaganda', The American Political Science Review, Vol. 21, No. 3. (Aug., 1927), 627-631.

Lippmann, W. (1998). Public Opinion, New Brunswick, NJ: Transaction (original 1922, New York: Macmillan).

Morris, T. \& Goldsworthy, S. (2008). PR - A Persuasive Industry? Spin, Public Relations and the Shaping of the Modern Media, Houndmills: Palgrave.

Newman, N. (2004). 'Introduction to the UK edition' in Stauber, J. \& Rampton, S. (2004) Toxic Sludge is Good for You. Lies, damn lies and the public relations industry, London: Robinson, ix-xv.

Packard, V. (2007). The Hidden Persuaders, New York: Ig Publishing (original 1957).

Pearson, J. \& Turner, G. (1965). The Persuasion Industry, London: Eyre \& Spottiswoode.

Perelman, C. \& Olbrecths-Tyteca, L. (1976). Traité de l'argumentation. La nouvelle rhétorique, Bruxelles: Éditions de l'Université de Bruxelles.

Petty, R. E. \& Cacioppo, J. T (1996). Attitudes and Persuasion: Classic and Contemporary Approaches, Boulder, Oxford: Westview Press.

Pinheiro, A. E. (2003). 'Xenofonte. Apologia de Sócrates', Máthesis, 12, 133-164.

Plataforma Sabor Livre et al. (2009, 30 de Abril). Campanha da EDP subverte realidade sobre barragens, [http://www.quercus.pt/scid/webquercus/defaultArticleViewOne.asp? categoryID=567\&articleID=2805, consultado em 18/05/09].

Platão (1993). 'Apologia de Sócrates' in Platão (1993) Eutifron. Apologia de Sócrates. Críton, Lisboa: Imprensa Nacional-Casa da Moeda, 57-100.

Público (2009, 23 de Abril). 'EDP investe 3000 milhões de euros em barragens até 2016' [http://ww2.publico. clix.pt/print.aspx?id=1376281\&idCanal=undefined, consultado em 18/05/2009].

Público (2009, 30 de Abril). 'Ambientalistas acusam campanha da EDP de branquear efeitos das barragens' [http://ww2.publico.clix.pt/print.aspx?id=1377858\&idCanal=undefined, consultado em 18/05/2009].

Sol (2009, 24 de Abril). 'Paulo Gonzo dá concerto a 340 metros de profundidade na barragem do Alto Lindoso’ [http://sol.sapo.pt/Common/print.aspx, consultado em 18/05/2009].

Sol (2009, 13 de Junho). 'Ambientalistas cortam trânsito no paredão da Barragem de Belver' [http://sol.sapo. pt/PaginaInicial/Sociedade/Interior.aspx?content_id=138286, consultado em 4/08/2009].

Stauber, J. \& Rampton, S. (2004). Toxic Sludge is Good for You. Lies, damn lies and the public relations industry, London: Robinson.

TSF (2009, 10 de Maio). Barragens como energia renovável e segurança energética [http://tsf.sapo.pt/ Programas/programa.aspx?content_id=1224997\&audio_id=1226177, consultado em 04/08/2009].

TSF (2009, 31 de Maio). Os impactos ambientais provocados pela construção de uma barragem [http://tsf.sapo. pt/Programas/programa.aspx?content_id=1224997\&audio_id=1248374, consultado em 04/08/2009].

TSF (2009, 26 de Julho). Barragem de Ribeiradio [http://tsf.sapo.pt/Programas/Programa.aspx?content $\mathrm{id}=1224997$, consultado em 04/08/2009].

Tye, L. (2002). The Father of Spin: Edward L. Bernays and The Birth of Public Relations, New York: Owl Books.

Visão (2009, 30 de Abril). 'Ambientalistas acusam campanha da EDP de branquear efeitos das barragens' [http:// aeiou.visao.pt/gen.pl?p=print\&op=view\&fokey=vs.stories/506734\&sid=vs.sect, consultado em 18/05/2009]. 


\section{ANEXO 1}

\begin{tabular}{|c|c|c|c|}
\hline MEIO & TÍTULO & LANÇAMENTO DA CAMPANHA & REALIZAÇÃO DA CAMPANHA \\
\hline $\begin{array}{l}\text { Comunicados } \\
\text { no site da } \\
\text { EDP, } 23 \text { e } 24 \\
\text { de Abril de } \\
2009\end{array}$ & $\begin{array}{l}\text { "EDP investe } \\
3000 \text { milhões } \\
\text { de euros em } \\
\text { barragens até } \\
2016 \text { " } \\
\text { "EDP lança } \\
\text { nova campanha } \\
\text { institucional } \\
\text { dedicada à } \\
\text { energia hídrica" }\end{array}$ & $\begin{array}{l}\text { “A EDP lança, dia } 24 \text { de } \\
\text { Abril, a nova campanha de } \\
\text { publicidade com o objectivo } \\
\text { de sensibilizar os portugueses } \\
\text { para a importância da energia } \\
\text { hídrica no desenvolvimento } \\
\text { do país. Sob o mote 'Quando } \\
\text { projectamos uma barragem, } \\
\text { projectamos um futuro melhor', } \\
\text { esta campanha multimeios - } \\
\text { televisão, cinema, imprensa, } \\
\text { rádio, mupis, internet e } \\
\text { edifícios EDP - visa divulgar } \\
\text { o compromisso do Grupo na } \\
\text { defesa do ambiente e melhoria } \\
\text { da qualidade de vida das } \\
\text { populações.” (Lead e primeiro } \\
\text { parágrafo) (24 de Abril) }\end{array}$ & $\begin{array}{l}\text { “A EDP vai construir cinco } \\
\text { novos empreendimentos } \\
\text { hidroeléctricos (Baixo Sabor, } \\
\text { Foz Tua, Fridão, Alvito e } \\
\text { Ribeiradio). A estes projectos, } \\
\text { somam-se os reforços de } \\
\text { potência em algumas das } \\
\text { barragens do actual parque } \\
\text { hídrico da EDP (Bemposta, } \\
\text { Picote, Alqueva, Venda Nova, } \\
\text { Salamonde e Paradela). No } \\
\text { total, a EDP investirá neste } \\
\text { conjunto de projectos cerca de } \\
3000 \text { milhões de euros. Quando } \\
\text { concluído, em } 2016 \text {, o plano } \\
\text { de investimentos aumentará } \\
\text { a capacidade instalada em } \\
\text { mais } 2900 \text { MW. Um reforço } \\
\text { de } 61 \% \text { face ao actual parque } \\
\text { hidroeléctrico do grupo.” } \\
\text { (primeiro e segundo parágrafos) } \\
\text { (23 de Abril) }\end{array}$ \\
\hline $\begin{array}{l}\text { Expresso, } 24 \\
\text { de Abril de } \\
2009\end{array}$ & $\begin{array}{l}\text { "Gonzo dá } \\
\text { concerto a } \\
340 \text { metros de } \\
\text { profundidade" }\end{array}$ & $\begin{array}{l}\text { “A EDP arranca hoje a sua } \\
\text { nova campanha institucional } \\
\text { com um concerto de Paulo } \\
\text { Gonzo na barragem do Alto } \\
\text { Lindoso, numa sala situada a } \\
340 \text { metros de profundidade. } \\
\text { A nova campanha institucional } \\
\text { 'Quando Projectamos uma } \\
\text { Barragem, Projectamos } \\
\text { um Futuro Melhor' vai ser } \\
\text { adaptada para a televisão, } \\
\text { cinema, imprensa, rádio, } \\
\text { mupis e Internet e vai estar } \\
\text { presente nos edifícios da EDP.” } \\
\text { (primeiro parágrafo) }\end{array}$ & $\begin{array}{l}\text { “A EDP prevê concluir } \\
\text { até } 2016 \text { cinco novos } \\
\text { empreendimentos } \\
\text { hidroeléctricos (Baixo Sabor, } \\
\text { Foz Tua, Fridão, Alvito e } \\
\text { Ribeiradio) e reforçar a } \\
\text { potência em algumas das } \\
\text { barragens do actual parque } \\
\text { hídrico (Bemposta, Picote, } \\
\text { Alqueva, Venda Nova, } \\
\text { Salamonde e Paradela). Um } \\
\text { conjunto de projectos que } \\
\text { representa um investimento } \\
\text { de cerca de } 3 \text { mil milhões } \\
\text { de euros, indica a empresa. } \\
\text { Quando concluído o plano de } \\
\text { investimentos, aumentará a } \\
\text { capacidade instalada em mais } \\
2900 \text { megawatts e representará } \\
\text { um reforço de } 61 \% \text { face ao } \\
\text { actual parque hidroeléctrico } \\
\text { do grupo." (Dois últimos } \\
\text { parágrafos) }\end{array}$ \\
\hline
\end{tabular}




\begin{tabular}{|c|c|c|c|}
\hline $\begin{array}{l}\text { Jornal de } \\
\text { Notícias, } 24 \\
\text { de Abril de } \\
2009\end{array}$ & $\begin{array}{l}\text { "Paulo Gonzo } \\
\text { canta a } 340 \\
\text { metros de } \\
\text { profundidade" }\end{array}$ & $\begin{array}{l}\text { “A EDP arranca esta sexta- } \\
\text {-feira com a nova campanha } \\
\text { institucional com um concerto } \\
\text { de Paulo Gonzo na barragem } \\
\text { do Alto Lindoso, numa sala } \\
\text { situada a } 340 \text { metros de } \\
\text { profundidade. } \\
\text { A nova campanha institucional } \\
\text { 'Quando Projectamos uma } \\
\text { Barragem, Projectamos } \\
\text { um Futuro Melhor' vai ser } \\
\text { adaptada para a televisão, } \\
\text { cinema, imprensa, rádio, } \\
\text { mupis e internet e vai estar } \\
\text { presente nos edifícios da EDP.” } \\
\text { (primeiro e segundo parágrafos) }\end{array}$ & $\begin{array}{l}\text { “A EDP prevê concluir } \\
\text { até } 2016 \text { cinco novos } \\
\text { empreendimentos } \\
\text { hidroeléctricos (Baixo Sabor, } \\
\text { Foz Tua, Fridão, Alvito e } \\
\text { Ribeiradio) e reforçar a } \\
\text { potência em algumas das } \\
\text { barragens do actual parque } \\
\text { hídrico (Bemposta, Picote, } \\
\text { Alqueva, Venda Nova, } \\
\text { Salamonde e Paradela). Um } \\
\text { conjunto de projectos que } \\
\text { representa um investimento } \\
\text { de cerca de } 3 \text { mil milhões de } \\
\text { euros, indicou a empresa. } \\
\text { Quando concluído o plano de } \\
\text { investimentos, aumentará a } \\
\text { capacidade instalada em mais } \\
\text { 2900 megawatts e representará } \\
\text { um reforço de } 61 \text { por cento face } \\
\text { ao actual parque hidroeléctrico } \\
\text { do grupo.” (Dois últimos } \\
\text { parágrafos) }\end{array}$ \\
\hline $\begin{array}{l}\text { Sol, } 24 \text { de } \\
\text { Abril de } 2009\end{array}$ & $\begin{array}{l}\text { "Paulo Gonzo } \\
\text { dá concerto a } \\
340 \text { metros de } \\
\text { profundidade } \\
\text { na barragem do } \\
\text { Alto Lindoso" }\end{array}$ & $\begin{array}{l}\text { "A EDP vai hoje arrancar a sua } \\
\text { nova campanha institucional } \\
\text { com um concerto de Paulo } \\
\text { Gonzo na barragem do Alto } \\
\text { Lindoso, numa sala situada a } \\
340 \text { metros de profundidade. } \\
\text { A nova campanha institucional } \\
\text { "Quando Projectamos uma } \\
\text { Barragem, Projectamos um } \\
\text { Futuro Melhor" vai ser } \\
\text { adaptada para a televisão, } \\
\text { cinema, imprensa, rádio, mupis } \\
\text { e internet e vai estar presente } \\
\text { nos edifícios da EDP. (Lead e } \\
\text { primeiro parágrafo) }\end{array}$ & $\begin{array}{l}\text { “A EDP prevê concluir } \\
\text { até } 2016 \text { cinco novos } \\
\text { empreendimentos } \\
\text { hidroeléctricos (Baixo Sabor, } \\
\text { Foz Tua, Fridão, Alvito e } \\
\text { Ribeiradio) e reforçar a } \\
\text { potência em algumas das } \\
\text { barragens do actual parque } \\
\text { hídrico (Bemposta, Picote, } \\
\text { Alqueva, Venda Nova, } \\
\text { Salamonde e Paradela). Um } \\
\text { conjunto de projectos que } \\
\text { representa um investimento } \\
\text { de cerca de } 3 \text { mil milhões de } \\
\text { euros, indicou a empresa. } \\
\text { Quando concluído o plano de } \\
\text { investimentos, aumentará a } \\
\text { capacidade instalada em mais } \\
\text { 2900 megawatts e representará } \\
\text { um reforço de } 61 \text { por cento face } \\
\text { ao actual parque hidroeléctrico } \\
\text { do grupo." (Dois últimos } \\
\text { parágrafos) }\end{array}$ \\
\hline
\end{tabular}

